\title{
MECHANISMS FOR RISK ELIMINATION OF A COMPLIANCE TRAP IN THE BRAZILIAN TELECOMMUNICATIONS INDUSTRY
}

\author{
GUILHERME A. SANA ${ }^{1}$ \\ http://orcid.org/0000-0002-3679-029X \\ EDSON R. GUARIDO FILHO \\ http://orcid.org/0000-0001-7905-1596
}

To cite this paper: Sana, G. A., \& Guarido, E. R., Filho. (2021). Mechanisms for risk elimination of a compliance trap in the Brazilian telecommunications industry. Revista de Administração Mackenzie, 22(5), 1-26. doi:10.1590/1678-6971/eRAMR210179

Submission: Dec. 19, 2019. Acceptance: Nov. 18, 2020.

1 Positivo University (UP), Curitiba, PR, Brazil.

2 Positivo University (UP) and Federal University of Parana (UFPR), Curitiba, PR, Brazil.

\section{(c) $\mathbf{B Y}$

This paper may be copied, distributed, displayed, transmitted or adapted for any purpose, even commercially, if provided, in a clear and explicit way, the name of the journal, the edition, the year and the pages on which the paper was originally published, but not suggesting that RAM endorses paper reuse. This licensing term should be made explicit in cases of reuse or distribution to third parties.

Este artigo pode ser copiado, distribuído, exibido, transmitido ou adaptado para qualquer fim, mesmo que comercial, desde que citados, de forma clara e explícita, o nome da revista, a edição, o ano e as páginas nas quais o artigo foi publicado originalmente, mas sem sugerir que a RAM endosse a reutilização do artigo. Esse termo de licenciamento deve ser explicitado para os casos de reutilização ou distribuição para terceiros. 


\section{ABSTRACT}

Purpose: This study aims to analyze how the Brazilian National Communications Agency (Agência Nacional de Telecomunicações - Anatel) and cellular operators in Brazil used ceremonial and discursive practices to build enforcement and compliance actions, adopted during a period of crisis in the cellular sector industry in 2012 when the legitimacy of the respective regulatory model and the regulatory agent were challenged, shaping a compliance trap situation.

Originality/value: The work fills a theoretical gap by associating the normative-cultural perspective of regulation associated with organizational institutionalism, based on the assertion that the relationship between regulator and regulated is interactive and not unidirectional, allowing that enforcement mechanisms represent political efforts, realigning the interests of the actors within their institutional environments.

Design/methodology/approach: The case study research strategy with a qualitative approach is adopted, studying the 2012 crisis in the cellular sector industry, with the collection of data from documentary sources and semi-structured interviews with participants in the process.

Findings: The results show that, in the compliance trap situation, symbolic criteria can appropriate the speeches, producing texts and practices in favor of legitimizing the enforcement mechanisms and the respective compliance responses in view of the audience. Therefore, the compliance trap risk on the regulatory agent is mitigated to the extent that ceremonial and discursive practices manifest themselves responsively and gain political and cultural support, reducing social pressure on the legitimacy of the regulation model.

\section{KEYWORDS}

Ceremonialism. Legitimacy. Regulation. Telecommunications. Compliance trap. 


\section{INTRODUCTION}

When regulatory agencies are unable to apply harsher sanctions to their regulated companies, motivated by non-compliance with their obligations and in the face of pressure from society to reestablish the normal functional conditions of the operations of these companies, there is a predisposition that there may be a regulator - regulated negotiation that results in the construction of enforcement and compliance measures tolerable for both parties (Lokanan, 2015; Ahmad, 2018; Erp, Wallenburg, \& Bal, 2018). This situation is typical for the risk of the emergence of the compliance trap (Parker, 2006, 2014), with the challenge of the regulator's legitimacy and the enforcement and compliance mechanisms. The work presented here aims to show that the effects of the compliance trap can be mitigated through discursive and ceremonial practices. This proposition is based on the consideration of intertwining legal and organizational fields (Edelman, 2016) in the political support that will promote the mitigation of the effects of the compliance trap (Parker, 2006, 2014).

In Brazil, the case of the National Telecommunications Agency (Agência Nacional de Telecomunicações - Anatel) and cellular operators can be analyzed in light of the framework described. Motivated by pressure from society and the government, in July 2012, Anatel adopted sanctions against operators due to their operational deficiencies, prohibiting them from selling new accesses until they presented investment and improvement plans. In parallel with the application of sanctions, there was an apparatus that comprised: 1. statements by authorities emphasizing the rigor of such sanctions; 2 . calling on operators to present specific investment and improvement plans; 3. interviews with executives; and 4. public announcements from operators, lamenting the severity of the sanctions and promising to continue with the good service provided. During the process of preparing and presenting the plans required for the release of sales, there were several meetings between Anatel and the operators, with wide dissemination of their results through the press.

These meetings characterized the existing interaction in the social construction of the environment in which both regulator and regulated, operate. Our argument is that this situation is characterized by the overlapping of the legal and organizational fields (Edelman, 2016), specifically in the construction of enforcement and compliance actions in the negotiation process that took place between Anatel and the cellular operators. Besides that, under this framework, there is a condition supported by the articulation of 
common interests that make conformity tolerable and even advantageous for the actors involved (Coslovsky, Pires, \& Silbey, 2010), or, in amalgamated solutions, that will represent alternative solutions for the problems of business and regulators (Gilad, 2014).

The speeches by both Anatel and the operators were preponderant in the construction of enforcement and compliance actions as a means of favoring the legitimacy of Anatel's regulatory model. On the other hand, the evidence of the ceremonialism of the process was initially shown by the affirmation of some consultants and press organizations that stated that there was a certain "theatricality" and "pyrotechnics" in such a process. An executive from this industry classified the suspension of sales by cellular operators as pretty mediatic. Subsequently, it was found that the measures adopted did not result in any change in the results in the companies, both on the customer base and in service revenue. In addition, the volume of complaints on the Anatel website has returned to practically the same rates as before the initiatives, supported by pronouncements by Anatel's presidency stressing that the expected results had not yet been achieved.

These aspects are related to Anatel's need to avoid the establishment of a compliance trap (Parker, 2006, 2014), a situation marked by the challenge of the legitimacy of the regulator and enforcement mechanisms, making it difficult to apply punitive sanctions or the use of cooperative strategies based on moral demands, informal pressures, indirect threats and normative internalization of compliance principles. It is a trap because, on the one hand, the lack of political and cultural support from the regulator weakens it in the face of an eventual conflict with the regulated ones, less likely to compromise with the regulator's demands and more likely to engage in a political confrontation, for example, lobbying to weaken the regulator's enforcement power. On the other hand, it is also a trap because the regulatory agent, in this situation, can choose to remain immobilized, with no impact on compliance. In one way or another, it will depend on political mechanisms to overcome the impasse. In this article, it is argued that the 2012 cellular crisis brings elements to a compliance trap situation, which was mitigated through discursive and ceremonial articulation for its legitimacy.

In view of the above, more specifically, this paper analyzed how Anatel and cellular operators used ceremonial and discursive practices to contain the effects of the compliance trap situation designed back then. In this context, the relationship between regulator and regulated took place in the sense of building measures that symbolized the adoption of enforcement and compliance practices in response to the challenge of the legitimacy of 
the respective regulatory model and the regulatory agent itself during the crisis period in the telephony sector in 2012.

To address this issue, this article is structured in six sections. In addition to this introduction, two sections express the theoretical support for the development of the research, respectively the notion on the institutional perspective of regulation and topics on the use of discursive and ceremonial practices in the search for the legitimacy of socially constructed regulation as a way to mitigate the compliance trap. Then, there is the description of the methodology adopted in the research; after that, there is the section with the presentation of the case and analysis of the findings, with the respective confrontation with the theoretical review used. The article concludes the final remarks with a synthesis of what is expressed throughout the text and with a suggestion for the development of research in other segments of regulation in Brazil.

\section{INSTITUTIONAL PERSPECTIVE OF REGULATION}

The mutual influence between organizations and institutions (North, 2018) supports this work: adopting this perspective in the analysis of laws and organizations, it can be said that both constitute overlapping social fields. Looking further into the legal fields, they understand the legal institutions (courts, legislatures, and administrative agencies), the various legal actors working in and around legal institutions, formal laws, informal norms and principles involving formal law, and also the flows of influence, communication, and innovation concerning legal ideas and standards (Edelman, 2016).

The multiple points of overlap between organizational and legal fields become more evident when, in the terms put forward by Edelman (2016), organizations seek to influence the legal institutions that regulate them, through the processes of interaction in litigation situations and in those cases in which they interpret the law to generate particular forms of compliance.

Under these conditions, the overlap treated here allows the flow of ideas between the two fields to provide the infusion of ideas and business values in the law or, more pragmatically, to make the legal norms be filtered through the organization's lens, leading to a new conceptualization of the law in which symbolic structures become acceptable forms of compliance (symbolic structures being understood as those that evoke the notion of legality or legitimacy without necessarily implying their effectiveness) (Edelman, 2016). 
Transporting these concepts to the context of regulation, Costa (2012) expresses that the simultaneous acting of regulators and regulated occurs through the temporal construction of revision of the agreement between such actors in a political perspective that seeks, through the affinity of interests, to make tolerable and even advantageous compliance for all the considered actors (Coslovsky et al., 2010; Short, 2019).

These statements adhere to the ideal type of regulation co-construction model established by Gilad (2014), in which the meaning of regulation and compliance is shaped by regulators and regulated in an interactive process of framing regulatory problems and their solutions, requiring that frames of both parties must be aligned on the consequences for organizations and the intentions of the regulators. Thus, the meaning and content of the regulations that emerge create the possibility of "amalgamated" solutions of the initial intentions of the regulators, wrapped in frames accessible to industry practices, establishing alternative solutions for business and regulator problems (Gilad, 2014).

Thus, enforcement and compliance mechanisms represent an essentially political effort, basically built by reaching agreements and arrangements between regulatory agents and the regulated, realigning interests, assigning new forms to conflicts and promoting a new distribution of risks encompassed by the businesses involved and compliance laws and rules (Coslovsky et al., 2010; Short, 2019).

In these models, the so-called "regulator's dilemma" occurs, which is seen between accepting the reframing of their message by organizations or confronting them with their regulation constructions, at the risk of creating antagonism with these organizations, which could result in "cosmetic" or superficial compliance generated by this antagonism (Gilad, 2014).

The aspects observed in the previous paragraphs are supportive of the concept of responsive regulation, when they indicate the need to use other regulatory strategies to improve compliance more than the application of penalties in an isolation way, proposing that such strategies should be deposited at the base of the regulatory pyramid (Parker, 2006, 2014). More clearly, agencies interact with regulated entities, seeking cooperation situations in the event of initial non-compliance, avoiding the escalation of the regulatory pyramid (Lokanan, 2015), that is, avoiding the punitive sanctions that may arise (Ahmad, 2018).

In this situation, the responsive regulation literature suggests that enforcement actions represent an opportunity to generate a common understanding of how the visions of compliance should be according to the law. 
However, a conflict may arise between the parties, more specifically, when the regulators' stance understood as certain does not find an echo with the regulated (Parker, 2006, 2014). Furthermore, the behavior of regulators may, under different conditions, prove to be inappropriate under the eyes of society, characterized as not being very strict in trying to stop violations of laws and regulations (Mascini \& van Wijk, 2009), even more, the relevant regulations may lose legitimacy with audiences (Lokanan, 2015).

It is admitted that, in situations of this type, there is a risk of establishing the so-called compliance trap (Parker, 2006, 2014), manifested from the loss of the moral and political support of the enforcement regime, both by the authorities and by society, thus, leading to the impossibility for such audiences to endorse the model of regulation built so that the meaning of compliance within the model can be politically contested (Mascini \& van Wijk, 2009). In order to avoid this situation, the regulator must seek, with the said audiences, the legitimacy of the enforcement and compliance processes then built with the regulated ones, in an attempt to control the negative consequences of such processes (Mascini \& van Wijk, 2009).

As Parker $(2006,2014)$ explains, a compliance trap situation requires a political exit from the regulator (Short, 2019) in the social construction of the meaning of compliance, that is, its performance will be shaped by higher levels of political intervention and even pressured by media coverage and other forms of political pressure (Gilad, 2015).

In this political exit, three alternatives are pointed out by the author: 1. the regulator can bend to the regulated, accepting its interpretation of the legal meaning, admitting a lighter position on compliance; 2 . the regulator can appeal to the courts to exercise its enforcement power, even though it runs the risk that sanctions will still be interpreted as more advantageous than full compliance with the legal requirement, or that the regulator will be taxed as a punitive agent, with no effect on cultural change in favor of compliance; or 3 . the regulator can wait for a change of perspective on the part of the regulated, who would come to understand the sense of compliance and enforcement practices as appropriate. In the latter condition, there is a need for regulators to have the necessary communication or relational skills to enable regulation in order to correctly interpret signals in the sense of the required adequacy to the compliance requirements (Hard, Howe, \& Cooney, 2013).

The present work seeks to advance in the analysis of situations in which the regulator does not have political and social support for its action, tending to get stuck in the compliance trap, but using ceremonial and discursive mechanisms, manifested in the relationship between regulator and regulated, 
as an exit policy as emphasized here, will mitigate the risk of the compliance trap. The following section outlines the fundamentals that complement this perspective.

\section{REGULATION, LEGITIMACY, SPEECH, AND CEREMONIALISM}

As previously stated, the flow of ideas resulting from the overlap between the legal and organizational fields (Edelman, 2016) may cause the regulator and regulated to establish agreements in the construction of enforcement and compliance actions in such a way that the interests of both parties are in them contemplated (Coslovsky et al., 2010; Gilad, 2014; Short, 2019).

This process of construction of symbolic criteria by the parties - regulator and regulated - can appropriate speeches, seen as malleable variables that can be used for any result in order to create a social reality through texts and practices that will give meaning to the construction treated in this article, considering the political aspects and that can contemplate the interests of the actors (Hardy, Palmer, \& Phillips, 2000). The discourse, in the view of Schmidt (2011), constitutes a process of generating, deliberating, and/or legitimizing ideas about a determined political action in an institutional context.

In fact, in the process of the social construction of the meaning of compliance as a political solution to the compliance trap and within the suggested by Parker $(2006,2014)$ as the third alternative for this solution, the use of discursive and ceremonial mechanisms ${ }^{3}$ seems adequate for the search for legitimation with the audiences regarding the regulation model built. Then, in this process, there is a need to inform the audiences that the common understanding between the regulator and the regulated has been established regarding the sense of compliance and enforcement practices as appropriate to the current situation.

This need for communication is corroborated by Gilad, Maor, and Bloom (2015), who state that the reputation of a regulatory agency can be threatened in the face of the lack of communication regarding the recognition of problems with its regulators and with regard to actions that are being taken to minimize the verified regulatory dysfunction.

Ceremonial practices, according to Meyer and Rowan (1977), are linked to the symbolic adoption of products, services, techniques, policies, and programs, even without meeting efficiency criteria, to maintain conformity within institutionalized standards in society. 
In these conditions, the discursive process contemplated here comprises the construction of ideas in a political sphere "coordinated" by political actors and discussed in a "communicative" political sphere by actors and the public (Schmidt, 2011), that is, discursive interactions externalize ideas within institutional contexts with transformative power, exercising a causal influence on the political scene as a result of institutional change or continuity (Schmidt, 2008).

Thus, the speeches serve so that the actors at the center of the political construction can create their ideas, actions, and respective justifications coordinated between them, to communicate them to the general public in the search for the legitimation of their acts, in the process of persuasion of masses (Schmidt, 2008, 2011).

Despite communication to the audiences on the adequacy of the compliance and enforcement processes, the need remains to assure their social endorsement as effective for stopping violations of laws and regulations, even though pragmatically they were not.

In fact, when creating symbolic structures and the imperative of being seen as best practices, there is a need to seek legitimacy ${ }^{4}$ with audiences (Mascini \& van Wijk, 2009), in such a way that it becomes difficult to analyze divergences between real practices and formal legal procedures provided for in those situations (Edelman, 2016). Therefore, the law tends to operate in ceremonial dimensions that suggest the audience to comply with legal conditions, but with the decoupling ${ }^{5}$ of symbolic structures in relation to current organizational practices (Edelman, 2016).

In other words, symbolic structures show attention to the law, remaining legitimate, but with organizations maintaining flexibility in preserving their business practices, taking advantage of the legitimacy provided by these symbolic structures, without substantially changing their business practices (Edelman, 2016). In other words, there is a break of the "spirit of the law", that is, its perceived intention, without there being a literal break of the same law (Garcia, Chen, \& Gordon, 2014).

In short, regulators and regulated resort to the use of discursive and ceremonial resources in the search for legitimacy through manipulation,

\footnotetext{
4 "Perceived or generalized assumption that an entity's actions are desirable, adequate or appropriate within some socially constructed system of norms, values, beliefs, and definitions" (Suchman, 1995, p. 574).

5 In terms of Boxenbaum and Jonsonn (2008, p. 90), from Meyer and Rowan (1977), it is the "deliberate disconnection between organizational structures that confer legitimacy and organizational practices that are understood within the organization as technically efficient".
} 
conformation to environments, and the way in which texts can be used to gain legitimacy and support through consistent speeches, producing institutions that are more powerful because their self-regulatory mechanisms are mutually reinforcing (Phillips, Lawrence, \& Hardy, 2004).

In this way, regulators and regulated, acting as reciprocal legitimizing agents, reinforce the condition of enforcement and compliance mechanisms as an essentially political effort and jointly build legitimacy guidelines for mediators with audiences (Deephouse \& Suchman, 2008), thus, contributing to minimizing the risk of establishing the compliance trap, which could lead to the political challenge of compliance, therefore, challenging the construction of the intended regulation model.

\section{METHODOLOGICAL PROCEDURES}

This qualitative study adopted the theme of the relationship between discourse, ceremonialism, and legitimacy in the regulation process of the cellular sector. The research was conducted under the strategy of the case study due to the extensive amount of data available through documentary sources and professionals who experienced the development of the crisis in the cellular telephony industry during the period, focusing on the processes, meanings, and understandings related to this industry (Brazilian telecommunications), with all its interfaces with the government, direct and indirect administration bodies, legislatures and consumer protection bodies, in addition to their own relevance in terms of customers and revenues involved.

In the data collection, documentary sources were used, such as news and editorials published by the mainstream media, as well as specific publications by Anatel and the specialized website Teleco, from December 2001 to May 2013.

Press agencies at the national level were selected for their notorious relevance in general and business journalism, in addition to the Teleco and Anatel websites due to the ease of obtaining information from the telecommunications industry. In the data collection, 413 articles were initially selected through their respective titles. From this first search, after content analysis and verification of duplicity, 105 articles remained, duly synthesized and recorded in a database. The choice of articles occurred from the exclusion of those considered as repeated (different titles with the same text), news related to facts already covered in other selected articles, and those with the title or call referring to the crisis of July 2012, addressing, however, another industry theme. 
Subsequently, nine semi-structured interviews were conducted with informants considered essential for the research, including, among others, former managers of Anatel, directors of industry class entities, and executives of the two operators most affected by the measures imposed by Anatel in the context of the crisis under analysis. The former managers of Anatel, here considered as essential informants, had relevant participation in the application of the punishments to the operators, from their conception and decision to the conduct of the analysis processes of the proposed improvement plans; on the other hand, the executives interviewed were responsible for the institutional representation of their companies with Anatel.

Based on the suggestion of Zilber (2007), the data collected underwent the first codification, grouping them into frames, determined from Anatel's role as a regulatory and operational performance agent of the regulated companies, as well as from relevant events from all over the case in order to allow them, in the second stage of codification, to be associated with the proposed analytical categories. In this second stage, there was a recategorization of the coded data for the analytical categories established as ceremonial practices, discursive practices, legitimacy, and its socio-political and cultural-cognitive dimensions, in addition to the regulatory context and model. From this point on, it was possible to reconstruct the meanings of the speeches and the intentions of the actors (Godoi, 2006), using an interpretive perspective.

\section{COMPLIANCE TRAP AND ANATEL'S REGULATION MODEL}

Cellular telephony in Brazil started to be implemented in 1991 in regional state operators linked to a company called Telecomunicações Brasileiras (Telebras). The operation consisted of a business line parallel to the other services offered at the time, under the name of Cellular Mobile Service (SMC), transformed, in 2001, into a new cellular mobile communications service, the Personal Mobile Service (SMP). SMP operators accounted for $99.5 \%$ of the market, totaling approximately 265 million customers in May 2013, with revenues of BRL\$ 16 billion in the first quarter of that year.

In the situation of the study presented here, the role of Anatel's collecting agent with the operators should be highlighted. In 2012, it collected more than BRL\$ 7 billion among inspection fees, installation, grants, and the Fund for Universalization of Telecommunications Services (Futs), plus all 
other taxes and duties that are collected directly from the operators by the federal and state governments, causing punishments that could represent damage to the operators' billings, causing repercussions on the Central Bank's "collection security".

Another very sensitive difficulty that Anatel faced was related to one of its enforcement mechanisms for the application of fines when the regulations were violated. After all, this mechanism had proved to be an ineffective resource since the percentage of fines actually collected at the time was quite low (around 20\%) due to the administrative and judicial procedures that such processes presented.

Operators had accelerated growth in their customer bases, accompanied by an increase in the volume of lawsuits filed with consumer protection agencies, including on Anatel's own website. In 2011, complaints about services provided by cellular operators represented $7.99 \%$ of the total demands, submitted to public consumer protection agencies belonging to the National Consumer Protection System (Sindec), which was part of Procon (Consumer Protection Agency) from 25 Brazilian states. This percentage was surpassed only by the numbers of the credit card industry, which reached $9.21 \%$.

\section{(Figure 5.1)}

\section{SINDEC 2011: INDUSTRY DEMAND}

\begin{tabular}{llcc}
\multicolumn{1}{c}{ Position } & \multicolumn{1}{c}{ Area } & Total & $\%$ \\
\hline$\# 1$ & Credit card & 141,672 & $9.21 \%$ \\
\hline$\# 2$ & Cellular telephony & 122,952 & $7.99 \%$ \\
\hline$\# 4$ & Fixed telephony & 85,606 & $5.56 \%$ \\
\hline$\# 5$ & Cellphone & 83,649 & $5.44 \%$ \\
\hline$\# 11$ & Cable TV & 32,276 & $2.10 \%$ \\
\hline$\# 14$ & Internet (services) & 27,826 & $1.81 \%$ \\
\hline Total & & $1,538,483$ & $100 \%$ \\
\hline
\end{tabular}

Source: Adapted by the authors based on the Teleco website (2013).

Due to this situation and still motivated by the various actions demanded by the Public Prosecutor's Office and Procon from several states, the Federal Justice, in addition to the pressure exerted by the Federal Audit Court, the Ministry of Communications, and the Presidency of the Republic, Anatel decided to prohibit operators TIM, Claro and Oi from selling accesses across 
the country, as of July 23, 2012. In each federative unit, an operator had its sale prohibited, as shown in Figure 5.2.

\begin{tabular}{ll} 
& (Figure 5.2) \\
& \multicolumn{1}{c}{ SUSPENSION OF SALES BY OPERATORS } \\
\hline Operator & \multicolumn{1}{c}{ Federative units } \\
\hline Oi & Amazonas, Rondônia, Amapá, Mato Grosso do Sul, and Rio Grande do Sul \\
\hline Claro & Sergipe, São Paulo, and Santa Catarina \\
\hline TIM & $\begin{array}{l}\text { Paraná, Rio de Janeiro, Espírito Santo, Minas Gerais, Bahia, Alagoas, Pernambuco, } \\
\text { Paraíba, Rio Grande do Norte, Ceará, Piauí, Maranhão, Tocantins, Distrito Federal, } \\
\text { Goiás, Mato Grosso, Pará, Acre, and Rondônia }\end{array}$ \\
\hline
\end{tabular}

Source: Folha de S.Paulo, July 19, 2012, Caderno Mercado B1.

In order to define the criteria used in the punishments, the agency carried out a systemic analysis of the complaints registered with its ombudsman between January 2011 and June 2012 and decided to punish one operator per state for not leaving the consumer without options of choice. However, it stands out that all operators, although far from a framework of excellence, had quality numbers within the technical goals established and supervised by Anatel.

Anatel informed that it would only release sales in the states when the aforementioned operators presented improvement plans that met the requirements in four areas: network quality, call completeness, end of call drops, and customer service. The agency also demanded from the operator Vivo the presentation of a plan to improve the quality of the services provided.

The aspects described in this section refer to a situation that adheres to the theoretical framework of the compliance trap in its various dimensions. Firstly, there were pressures from society and the government for the effective compliance of operators in terms of perceived quality. However, Anatel could not adopt more stringent enforcement actions, both for the inefficiency of the fines process and mainly for the fact that penalties that could bring a reduction of operators' revenues would compromise the "collection security" recommended by the Central Bank, given the large volume of fees and taxes that the industry provides.

Perhaps the most important dimension of the compliance trap in the situation described here concerns the possibility of conflict with the regulated operators in the event of drastic punishments, a dispute that could be brought before the courts, especially considering the fact that the operators 
obeyed the compliance rates of quality measures proposed by Anatel. In view of these conditions that generate the compliance trap, Anatel did not have any other option within the third alternative proposed by Parker (2006, 2014), except to build the sense of enforcement and compliance with the operators. However, under these conditions, there is a need to seek cultural and political support for the new model built, without which the effects of the compliance trap cannot be mitigated since this support is critical for the new model to be considered appropriate before the various audiences. This search for cultural and political support for the new regulatory model developed was centered on discursive and ceremonial practices, analyzed in the development of the next sections.

\subsection{Ceremonialism and discursive practices}

In the series of meetings that followed between operators and Anatel, both of a technical nature and between managers, there were several public pronouncements from both parties, with great concern to the dissemination of speeches that denote the great effort of the parties in developing and attributing ideas from the existence of intense work to establish plans that would result in the improvement of services, subject to Anatel's rigor, even though a deadline was allowed for the objectives to be met. In this perspective, considering the strong influence of the speeches, Schmidt $(2008,2011)$ evokes them as a process of political construction that aims to resonate with audiences in the search for the legitimacy of the regulation model and, at the same time, maintaining the agency's reputation (Gilad, Maor, \& Bloom, 2015). Such speeches underscored the rigor and the demands expressed by the agency's enforcement and, at the same time, the compliance with what is determined by such enforcement is observed.

Therefore, Anatel's rigorous approach to the issue was translated into an article in the newspaper Valor Econômico on July 24, 2012. When reproducing the words of the Superintendent of Private Services, the article stated that Anatel showed that it would be rigorous when approving the plans, the operators would have meetings every day of the week, and the projection of the companies' demand should take into account the number of customers that the operator would have, its network capacity and, still, the marketing strategy should be linked to that of investments. On the other hand, Anatel's willingness to build the solution was also highlighted by Anatel through the same informant when it commented that the operators had done their "homework", even though the plans had to undergo adjustments. 
This whole process of presenting improvement plans by operators to meet Anatel's requirements, with operators doing their "homework", is in line with what Costa (2012) indicates as a revised temporal construction according to the actors involved, in a political perspective in which these actors, through common interests, make conformity tolerable for all (Coslovsky et al., 2010; Short, 2019).

Thus, the speeches were used respectively: to build the enforcement represented by the meetings and the requirements for investment and improvement plans by the agency; and for compliance, by observing operators regarding the requirements and immediate disclosure to the audience in search for resonance, aiming at consolidating the legitimacy of Anatel's regulatory model in a connection between action and discourse, with the production of texts aimed at understanding the intended manner (Phillips et al., 2004).

This analysis of Anatel's actions demonstrates the symbolic content of such acts, the reasons for which they are linked to the legitimation of its regulatory model (Lokanan, 2015), which became imperative, given that, as Morgan and Yeung (2007) point out, the conversation and cooperation with regulators in the impossibility of stronger actions creates a situation of less credibility for the regulatory agency (Gilad et al., 2015), which represents the compliance trap, especially due to the previous pressures with the audiences identified as sources of legitimacy (Deephouse \& Suchman, 2008), that is, the federal government and society.

The ceremonialism adopted by Anatel in the pursuit of legitimizing its regulatory model was highlighted by an editorial in the newspaper Folha de S.Paulo, who questioned the "theatricality" and political gesticulation of the measure. The consultant Eduardo Tude, president of Teleco, a consultancy specialized in telecommunications, considered that the suspension of sales should have little effectiveness in the short term, classifying the action as "pyrotechnics".

Recalling the situations in which constructed symbolic criteria meet the needs of regulators without fundamentally breaking the routines established in the industry (Edelman \& Suchman, 1997), the process of suspending sales seemed to have a day to end, given the proximity to the Father's Day, which represents a significant sales potential for the industry. The nonrelease by the regulatory agency up to that date would imply sales restrictions and, possibly, collection issues by Anatel, which could bring wear and tear between the agency and the government. In fact, sales were released prior to Father's Day, with the improvement plans presented by the operators and approved by Anatel. 
An executive connected to one of the industry's professional associations emphasized the ceremonial aspect of the whole process:

In conducting the discussions on the plans with the operators, part of Anatel's process was media-driven, as it is under pressure from civil society and public bodies and needs to satisfy these segments. The issue of quality of service is a very complex aspect, the plans that the companies presented, with investments, in the range of billions of Reais, evidently were not elaborated in a week, they already existed, maybe there was a forecast of execution in less time than those previously established (Informant A).

In fact, the elaboration and presentation of the plans by the operators show signs of ceremonialism in their essence, as pointed out by the executives of TIM and Claro, emphasizing that the plans had been consistent in their deadlines and evolution indicators, although assembled with information already existing in the companies, presented in a "new system".

In addition, TIM, through its director of regulatory affairs, declared to the press that they did not intend to increase the investment forecast for the year, only reallocating BRL $\$ 450$ million in network investments. Claro, in the words of one of its executives, also indicated only anticipations of investments already scheduled. Likewise, Oi also signaled only the reallocation of investments, whereby its planning vice president promised to invest BRL $\$ 2$ billion in actions to improve service, albeit without adding to those already scheduled for the coming years.

The verification of the effectiveness of the process as a whole can be evaluated from the results indicated by the agency and not achieved, seeming to indicate the decoupling in such actions. That is, the volume of complaints on the Anatel website in June and July 2013 was already presented in greater numbers than in the same months of 2012 (see Figure 5.1.1). In fact, it is important to remember that the volume of complaints on Anatel's website was the basis for determining the suspension of sales in 2012.

The real scope of the punishments reflected in the companies' operational indexes can be evaluated by the fact that Anatel's measures do not seem to have affected the operators. It is so that there is an increase in the operators' net service revenue, as well as in the average number of minutes of service usage, in accordance with Figure 5.1.2, at the end of 2012 and in the first months of 2013. 


\section{(Figure 5.1.1)}

COMPLAINTS AT ANATEL FOR 1,000 ACCESSES IN SERVICE

\begin{tabular}{lcccc}
\hline Operator & June 12 & June 13 & July 12 & July 13 \\
\hline TIM & 0.240 & 0.340 & 0.320 & 0.391 \\
\hline Oi & 0.503 & 0.668 & 0.549 & 0.829 \\
\hline Claro & 0.344 & 0.433 & 0.438 & 0.467 \\
\hline Vivo & 0.202 & 0.302 & 0.227 & 0.344 \\
\hline
\end{tabular}

Source: Anatel (2013)

(Figure 5.1.2)

CONSOLIDATED NET SERVICE REVENUE AND ANNUAL CUSTOMER BASE

\begin{tabular}{lccccccccccc}
\hline & \multicolumn{3}{c}{$\begin{array}{c}\text { Net service revenue } \\
\text { (BRL\$ million) }\end{array}$} & \multicolumn{5}{c}{$\begin{array}{c}\text { Annual consolidated customer base } \\
\text { (thousands) }\end{array}$} \\
\hline Operator & 2010 & 2011 & 2012 & $1 T 13$ & 2009 & 2010 & 2011 & 2012 & $1 T 13$ & May 13 \\
\hline Vivo & 17,229 & 19,587 & 21,398 & 5,636 & 51,744 & 60,293 & 71,554 & 76,137 & 75,988 & 76,097 \\
\hline TIM & 14,457 & 17,086 & 18,764 & 4,711 & 41,115 & 51,028 & 64,083 & 70,376 & 71,232 & 72,016 \\
\hline Claro & 11,764 & 12,993 & 12,760 & 3,148 & 44,401 & 51,638 & 60,380 & 65,238 & 66,038 & 66,517 \\
\hline Oi & ND & ND & 9,101 & 2,316 & 36,054 & 39,273 & 45,484 & 49,238 & 49,494 & 49,771 \\
\hline Others & $\ldots$ & $\ldots$ & $\ldots$ & $\ldots$ & 645 & 712 & 731 & 819 & 1,031 & 1,124 \\
\hline
\end{tabular}

The aspects of ceremonial practices observed in this study seem to be inseparable from the discourses used in the construction of enforcement and compliance actions and in the search for the legitimacy of the respective regulatory model. All of these aspects refer to what Machado-da-Silva and Vizeu (2007) express, in the sense that the whole process was not effectively connected to organizational performance but to the normative and/or cognitive-cultural criteria of the institutional field of reference.

In summary, it can be said that the enforcement of Anatel's regulatory model, within its pure conception as "law-on-the-books", had difficulties in its implementation either due to the very inefficiency of one of its main instruments (the imposition of fines) or to the impossibility of more drastic 
sanctions, such as the suspension of sales until the quality of the services provided was brought to levels perceived by users as satisfactory.

This last initiative would be impracticable, given that it would reduce the range of options offered to the public within each state of the federation and could still influence the billing of operators, thus, compromising Anatel's collection, offending the "collection security" aspect.

Under these conditions, Anatel had no alternative but to socially build enforcement with the operators and use compliance as one of the instruments to legitimize its regulation model, whose credibility was questioned. In this way, the speeches and all the associated ceremonial aspects are part of the construction discussed here. Moreover, they play an important role in defending the legitimacy of the existing regulation model. Thus, the possibility of establishing the compliance trap was minimized due to the fact that compliance actions were presented as legitimizing responses to enforcement, as can be seen from the participation in the meetings with the presentation of improvement plans, pronouncements on reallocations of investments, and speeches by operators' managers, at the end of the process, considering Anatel's measures to be "fair".

\subsection{Compliance trap and legitimization of the regulation model}

In situations of great repercussion, as in the case under study, there is a need to complement the models of the social construction of regulation by explaining mechanisms that aim to minimize the risks of establishing the compliance trap in a regime of enforcement and political challenge to compliance. These mechanisms aim to seek the legitimacy of socially constructed models with regulator and regulated organizations' respective audiences (Lokanan, 2015) and society. Discourses play an important role in this process by promoting discussion in the "communicative" political sphere among political actors and the public (Schmidt, 2011), externalizing ideas within institutional contexts, exercising a causal influence on political reality as a result of institutional change or continuity (Schmidt, 2008). In other words, communicating the coordinated ideas between these political actors to the general public in the search for the legitimation of their acts in the process of mass persuasion (Schmidt, 2008, 2011).

Working within this communicative logic, the present research identified, among its main findings, that enforcement and compliance mechanisms represent relevant objects of legitimation (Deephouse \& Suchman, 2008) of the regulation model built between regulator and regulated together 
with the main external source of legitimacy (Deephouse and Suchman, 2008), in this case, society as a whole, acting in a reciprocal manner throughout the process of constructing the model considered here.

These statements recover what was exposed by Deephouse and Suchman (2008) when they emphasize that a organization becomes legitimized when it is connected to others that are also legitimized. Within the scope of specific regulator-regulated relationships, there are elements verified in the research that suggest the reciprocity of legitimizing agents (Durand \& McGuire, 2005), who jointly build legitimation guidelines for mediators with the audience (Deephouse \& Suchman, 2008).

From this perspective of reciprocal legitimation, discursive strategies were decisive in mitigating compliance trap risks. Anatel's discursive strategies were developed along four main axes: 1. the "pyrotechnics" of the measures emphasized the rigor of the punishments: Anatel emphasized that it would treat the approval of quality improvement plans with great rigor, without which sales could not be resumed; 2 . Anatel's requirements were strict in establishing quality improvement plans and new investments: there would be daily meetings with operators, and the plans would have to contemplate demand projections, network capacity, and marketing strategies; 3 . the operators were aware of Anatel's rigor and were committed to the development of plans that met the agency's requirements: the operators actively participated in the meetings and were doing their "homework"; and 4. Anatel was aware that the improvement would not be immediate and that it would strongly accompany the execution of the plans: there would have to be time for the quality improvement plans by the operators to be implemented until the results could actually be perceived.

On the other hand, within the statements of Rojo and van Dijk (1997), emphasizing that legitimation can have the directions "top-down" and "bottom-up", an assertion verified in the participation of the operators in the construction of the legitimation of enforcement through compliance. This construction was represented by the elaboration of improvement plans and in the recognition that Anatel's measures were fair, as stated by TIM's president when he understood that his company was in a "process of inertia" due to investment delays and operational complexities motivated by the acquisitions of other operators. In the same direction, Vivo's president emphasized the difficulties in meeting Anatel's rigor due to the "extremely restrictive" laws for the installation of cellular antennas. TIM's executive, interviewed in this survey, points out that Anatel responded to what society demanded, although commenting that the situation could have been avoided by updating the sector's quality regulations. 


\section{CONCLUDING REMARKS}

The suspension of sales imposed by Anatel on operators as a punishment for the drop in quality perceived in the sector and the requirement for operators to prepare improvement plans, and also the series of meetings between regulators and regulated, characterized the existing interaction in the social construction of the environment in which the regulator and regulated act (Edelman, 2016), that is, the construction of enforcement and compliance actions in the negotiation process between Anatel and the cellular operators. Such built agreements refer to Coslovsky et al. (2010), who point out common interests that make conformity tolerable and even advantageous for the actors involved, or, in terms of Gilad (2014), in "amalgamated" outcomes that will represent alternative solutions to the problems of businesses and regulators.

The results verified in the research and which enabled the understanding of the construction process of the agreements mentioned here, in view of the search for mitigation of the compliance trap risk that Anatel would be subject to, are summarized in Figure 6.1.

\section{(Figure 6.1)}

\section{SUMMARY OF RESULTS}

\begin{tabular}{|c|c|}
\hline Discursive practices & $\begin{array}{l}\text { - Anatel's rigor in approving quality improvement plans. } \\
\text { - Operators aware of Anatel's rigor and doing their "homework". } \\
\text { - Requirements to meet the conditions of a number of customers versus } \\
\text { network capacity. } \\
\text { - The improvements would not be immediate, and Anatel would strongly } \\
\text { monitor the implementation of the plans presented. }\end{array}$ \\
\hline Ceremonialism & $\begin{array}{l}\text { - Theatricality and pyrotechnics in Anatel's actions. } \\
\text { - Plans presented that already exist in the operators and without any } \\
\text { increase in investments. } \\
\text { - No improvement in the complaint rates on Anatel's website. } \\
\text { - No influence of Anatel's measures on operators' operational indexes, } \\
\text { both in added customers and in minutes of use and net revenue. }\end{array}$ \\
\hline $\begin{array}{l}\text { Legitimization of the } \\
\text { regulation model }\end{array}$ & $\begin{array}{l}\text { - Enforcement and compliance as reciprocally legitimizing agents with } \\
\text { audiences, mitigating the compliance trap risk. }\end{array}$ \\
\hline
\end{tabular}

Source: Elaborated by the authors. 
The verified interaction process had a strong influence on the speeches by both Anatel and the operators. This interaction was used to build the enforcement represented by the meetings and requirements of investment plans and improvements by the agency. It was also used to build the compliance through the observation of the operators regarding the requirements of the regulator, with simultaneous disclosure to the audience in search for resonance, aiming at the elimination of the compliance trap, by consolidating the legitimacy of Anatel's regulatory model in a connection between action and discourse, with the production of texts aimed at understanding the way (Phillips et al., 2004).

Ceremonialism was present when the practices used seemed to be dissociated from the discourses used in the process of building enforcement and compliance and in the search for legitimacy. This was evident through the affirmation of some consultants and press organizations who said that there was a certain "theatricality" and "pyrotechnics" in such a process. It occurred to an industry executive to classify the process of suspending the sales of cellular operators as a mediatic act. In this sense, it is important to note that the measures adopted did not result in any change in the results of the companies, either in their customer base or in the service revenue. The volume of complaints on Anatel's website returned to practically the same rates as before the measures, and there were frequent speeches of the president of Anatel emphasizing that the expected results had not yet been achieved. That is, there was a break of the perceived intention of the regulations, but without breaking their respective formal content (Garcia et al., 2014). Therefore, as stated by Machado-da-Silva and Vizeu (2007), the process was not effectively connected to organizational performance but to the normative and/or cognitive-cultural criteria of the institutional field of reference.

Therefore, in situations where there is the emergence of a regulation model socially constructed along the lines of the case presented here, one should investigate the possibility of extending the concept of the regulation model to a greater extent when there is an associated legitimation system. That goes in addition to the legitimacy considered as purely organizational, and which may include the highlight of enforcement and compliance as agents of reciprocal legitimation for that socially constructed regulation model under the risk of a compliance trap.

Therefore, it would be of great value that, within the Brazilian context and its universe of regulatory agencies, further studies could be carried out that analyze the assertions placed in the previous paragraphs, based on the evidence verified in the present work, in other regulatory agents in the country. 


\section{MECANISMOS DE ELIMINAÇÃO DO RISCO DA COMPLIANCE TRAP NO SETOR DAS TELECOMUNICAÇÕES BRASILEIRAS}

\section{RESUMO}

Objetivo: Este estudo tem como objetivo analisar como a Agência Nacional de Telecomunicações (Anatel) e operadoras de telefonia celular utilizaram-se de práticas cerimoniais e discursivas para construir ações de enforcement e compliance adotadas durante o período de crise no setor celular em 2012, quando as legitimidades do respectivo modelo de regulação e do agente regulador foram contestadas, desenhando uma situação de compliance trap.

Originalidade/valor: O trabalho preenche uma lacuna teórica ao associar a perspectiva normativo-cultural da regulação associada com o institucionalismo organizacional, a partir da assertiva de que a relação entre regulador e regulados é interativa e não unidirecional, permitindo que os mecanismos de enforcement passem a representar esforços políticos, realinhando os interesses dos atores dentro de seus ambientes institucionais. Design/metodologia/abordagem: Adota-se aqui a estratégia de pesquisa de estudo de caso com abordagem qualitativa, de modo a avaliar a crise da telefonia celular de 2012, com a coleta de dados de fontes documentais e entrevistas semiestruturadas com participantes do processo.

Resultados: Os resultados mostram que, na situação de compliance trap, critérios simbólicos podem apropriar-se dos discursos, produzindo textos e práticas em favor da legitimação dos mecanismos de enforcement e das respectivas respostas da compliance à vista da audiência. Como consequência, mitiga-se o risco de compliance trap sobre o agente regulador na medida em que práticas cerimoniais e discursivas manifestam-se responsivamente e angariam suporte político e cultural, reduzindo a pressão social sobre a legitimidade do modelo de regulação.

\section{PALAVRAS-CHAVE}

Cerimonialismo. Legitimidade. Regulação. Telecomunicações. Compliance trap. 


\section{REFERENCES}

Ahmad, N. (2018). Responsive regulation and resiliency: The renewable fuel standard advanced biofuels. Virginia Environmental Law Journal, 36(2), 40-76.

Anatel (2013). Agência Nacional de Telecomunicações. Relatório Anual 2012-2013. Retrieved from www.anatel.gov.br

Boxebaum, E., \& Jonsson, S. (2008). Isomorphism, diffusion and decoupling. In R. Greenwood, C. Oliver, K. Sahlin, \& R. Sudabby (Orgs.), The Sage handbook of organizational institutionalism. London: Sage.

Coslovsky, S, Pires, R., \& Silbey, S. (2010). The pragmatic politics of regulatory enforcement (Working Paper No. 29). Jerusalem Papers in Regulation $\mathcal{E}$ Governance.

Costa, M. (2012). Educação e governança dos sistemas nacionais de recursos hídricos no período 1977-2010: Um estudo comparativo entre Brasil e Canadá (Dissertação de mestrado, Universidade Positivo, Curitiba, PR, Brasil).

Deephouse, D., \& Suchman, M. (2008). Legitimacy in organizational institutionalism. In R. Greenwod, C. Oliver, K. Sahlin, \& R. Sudabby (Orgs.), The Sage handbook of organizational institutionalism. London: Sage.

Durand, R., \& McGuire, J. (2005). Legitimating agencies in the face of selection: The case of AACSB. Organizations Studies, 26, 165-196. doi:101177/ 0170840605049465

Edelman, L., \& Suchman, M. (1997). The legal environments of organizations. Annual Review of Sociology, 23, 479-515. doi:10.1146/annurev.soc. 23.1.479

Edelman, L. B. (2016). Working law: Courts, corporations, and symbolic civil rights. London: The University of Chicago Press. doi:10.7208/Chicago/ 9780226400938.001.0001

Erp, J. van, Wallenburg, I., \& Bal, R. (2018). Performance regulation in a networked system: From cosmetic to institutionalized compliance. Public Administration, 98(1), 46-61. doi:10.1111/padm.12518

Garcia, S., Chen, P., \& Gordon, M. (2014). The letter versus the spirit of the law: A lay perspective on culpability. Judgment and Decision Making, 9(5), 479-490. 
Gilad, S. (2014). Beyond endogeneity: How firms and regulators co-construct the meaning of regulation. Law \& Policy, 36(2), 134-136. doi:10.1111/ lapo. 12017

Gilad, S. (2015). Political pressures, organizational identity and attention to tasks: Illustrations from pre-crisis financial regulation. Public Administration, 93 (3), 593-608. doi:10.1111/padm.12155

Gilad, S., Maor, M., \& Bloom, P. (2015). Organizational reputation, the content of public allegations and regulatory communication. Journal of Public Administration Research and Theory, 25(2), 451-478. doi:310.1093/jopart/ mut041

Godoi, C. (2006). Perspectivas de análise de discurso nos estudos organizacionais. In C. Godoi, R. Bandeira-de-Mello, \& A. Barbosa da Silva (Orgs.), Pesquisa qualitativa em estudos organizacionais (2a ed.). Sao Paulo: Saraiva.

Hard, T., Howe, J., \& Cooney, S. (2013). Less energetic but more enlightened? Exploring the fair work ombudsman's use of litigation in regulatory enforcement. The Sidney Law Review, 35, 565-597.

Hardy, C., Palmer, I., \& Phillips, N. (2000). Discourse as a strategic resource. Human Relations, 53, 1227-1248. doi:10.1177/0018726700539006

Lokanan, M. (2015). Securities regulation: Opportunities exist for IIROC to regulate responsively. Administration \& Society, 50(3), 402-428. doi:10.11 77/00953999715584637

Machado-da-Silva, C., \& Vizeu, F. (2007). Análise institucional de práticas formais de estratégia. Revista de Administração de Empresas, 47(4), 89-100.

Mascini, P., \& Wijk, E. van (2009). Responsive regulation at the Dutch food and consumer product safety Authority: An empirical assessment of assumptions underlying the theory. Regulation \& Governance, 3(1), 27-47. doi:10.1111/j.1748-5991.2009.01047.x

Meyer, J., \& Rowan, B. (1977). Institutionalized organizations: Formal structure as myth and ceremony. American Journal of Sociology, 83 (2), 340-363.

Morgan, B., \& Yeung, K. (2007). An introduction to law and regulation. Cambridge: Cambridge University Press.

North, D. C. (2018). Instituições, mudança institucional e desempenho econômico.

São Paulo: Três Estrelas. (Obra original publicada em 1990). 
Parker, C. (2006). The compliance trap: The moral message in responsive regulatory enforcement. Law \& Society, 40(3), 591-622.

Parker, C. (2014). The "compliance trap": The moral message in responsive regulatory enforcement. In E. Larson \& P. Schmidt (Eds.), The law and society reader II. New York: New York University Press.

Phillips, N., Lawrence, T., \& Hardy, C. (2004). Discourse and institutions. Academy of Management Journal, 29(4), 635-652. doi:10.2307/20159075

Rojo, L., \& Dijk, T. van (1997). “There was a problem, and it was solved!”: Legitimating the expulsion of "illegal" immigrants in Spanish parliamentary discourse. Discourse and Society, 8, 523-566. doi:10.1177/09579265 97008004005

Schmidt, V. A. (2008). Discursive institutionalism: The explanatory power of ideas and discourse. Annual Review of Political Science, 11, 303-326. doi:101146/annurev.polisci.11.060606.135342

Schmidt, V. A. (2011). Reconciling ideas and institutions through discursive institutionalism. In D. Béland \& R. Cox (Eds.), Ideas and politics in social science research. Oxford: Oxford University Press.

Short, J. L. (2019). The politics of regulatory enforcement and compliance: Theorizing and operationalizing political influences. Regulation \& Governance, Early View, 1-33. doi:10.1111/rego.12291

Suchman, M. (1995). Managing legitimacy: Strategic and institutional approaches. The Academy of Management Review, 20(3), 571-610. doi:1023 $07 / 258788$

Teleco (2013). Boletim Sindec. Retrieved from http://www.teleco.com.br/ procon.asp

Zilber, T. (2007). Stories and the discursive dynamics of institutional entrepreneurship: The case of Israeli high-tech after the bubble. Organization Studies, 28(7), 1035-1054.

\section{AUTHOR NOTES}

Guilherme A. Sana, Ph.D. from the Department of Management, Positivo University (UP); Edson R. Guarido Filho, Ph.D. from the Department of Management, Federal University of Paraná (UFPR). 
Guilherme A. Sana is now a member of the "Legal Environment and Organizations" Research Group of the Business School of UP; Edson R. Guarido Filho is now a full professor at the Business School of UP and associate professor at UFPR.

Correspondence concerning this article should be addressed to Guilherme A. Sana, Rua Professor Pedro Viriato Parigot de Souza, 5300, Programa de Pós-Graduação em Administração (PPGA), Campo Comprido, Curitiba, Paraná, Brazil, CEP 81280-330.

E-mail: gasana@terra.com.br

\section{EDITORIAL BOARD}

\section{Editor-in-chief}

Gilberto Perez

Associate editor

Maurício Reinert do Nascimento

Technical support

Vitória Batista Santos Silva

\section{EDITORIAL PRODUCTION}

Publishing coordination

Jéssica Dametta

Language editor

Daniel de Almeida Leão

Layout designer

Emap

Graphic designer

Libro 